\title{
Love-Hate for Man-Machine Metaphors in Soviet Physiology: From Pavlov to "Physiological Cybernetics"
}

\section{Slava Gerovitch}

Dibner Institute for the History of Science and Technology

Every new level achieved by technology attracted the attention of physiologists and turned their thoughts in a new direction; they often unwittingly modeled life processes in the image of contemporary engineering achievements.

- Nikolay Bernshteyn ([1958] 1997, 392)

\section{Argument}

This article reinterprets the debate between orthodox followers of the Pavlovian reflex theory and Soviet "cybernetic physiologists" in the 1950s and 60s as a clash of opposing manmachine metaphors. While both sides accused each other of "mechanistic," reductionist methodology, they did not see anything "mechanistic" about their own central metaphors: the telephone switchboard metaphor for nervous activity (the Pavlovians), and the analogies between the human body and a servomechanism and between the human brain and a computer (the cyberneticians). I argue that the scientific utility of machine analogies was closely intertwined with their philosophical and political meanings and that new interpretations of these metaphors emerged as a result of political conflicts and a realignment of forces within the scientific community and in society at large. I suggest that the constant travel of man-machine analogies back and forth between physiology and technology has blurred the traditional categories of the "mechanistic" and the "organic" in Soviet neurophysiology, as perhaps in the history of physiology in general.

\section{Introduction}

In the early 1960s the question whether machines can think and, more generally, the question of the value of man-machine metaphors became a matter of public debate in the Soviet Union. In April 1961, in a public lecture on "Automata and Life" before a crowd of one thousand that filled Moscow University's largest hall, the prominent mathematician Andrey Kolmogorov proclaimed:

If such qualities of a material system as "being alive" or "capable of thinking" are defined in a purely functional way (for example, any material system with which it is possible to discuss meaningfully some problems of contemporary science or literature will be called 
a "thinking system"), then one would have to admit that in principle living and thinking beings can be created artificially. (Kolmogorov 1963, 11; emphasis in original) ${ }^{1}$

The physiologist Yuriy Frolov responded to claims like this with a categorical statement that a machine could not think because it "lacks feedback that exists between man and the constantly changing social environment" (Frolov 1961, 316). Ironically, while trying to show the limitations of man-machine metaphors, he himself borrowed the term feedback from the language of cybernetics. Man-machine metaphors permeated public discourse so deeply that it proved impossible to step outside this metaphorical language even for the sake of criticizing it.

The advent of cybernetics pushed man-machine metaphors to the forefront of physiological debates. In the 1940s, a group of American and European mathematicians, engineers, physiologists, sociologists, and philosophers put forward cybernetics as a new research field built on the idea of unity of control and communication mechanisms in living organisms and in complex self-regulating machines. The mathematician Norbert Wiener, the physiologist Arturo Rosenblueth, and the engineer Julian Bigelow suggested that purposeful human behavior was governed by the same feedback mechanism that was employed in contemporary control devices, servomechanisms (Wiener [1948] 1961). The communication engineer Claude Shannon likened human communication to the transmission of electrical signals through a limited-capacity channel in the presence of noise (Shannon and Weaver 1949). The neurophysiologist Warren McCulloch and the mathematician Walter Pitts proposed a network of switch-like logical elements as a formal model of nervous activity (McCulloch and Pitts 1943). The mathematician John von Neumann compared the operation of a stored-program electronic digital computer to the human brain with its memorizing ability (Neumann 1958). Cyberneticians took such common physiological and psychological concepts as memory, homeostasis, and purpose, and extended them into the realm of machines. Physiologists, on the other hand, took such concepts as information, programming, and feedback out of their technical context, and applied them to living organisms. Cybernetics put into circulation new powerful cultural metaphors: "the body is a servomechanism," "the organism is an entropy-reducing machine," "the brain is a digital computer," "the mind is a universal logical machine," "human communication is transmission of information," and "thinking is computation."

Scientific metaphors do not simply transfer meaning from one term to another; they serve "as a medium of exchange between discourses, metaphors generate and transform scientific discourse and expose its textuality" (Bono 1990, 72). The concept of scientific discourse - an ensemble of diverse and often contradictory practices of producing, articulating, communicating, and manipulating scientific knowledge - lies at the center of my analysis. Built around appealing metaphors,

\footnotetext{
${ }^{1}$ Unless otherwise noted, all translations are the author's.
} 
discourses mix political, cultural, and technical meanings and mediate between the world of political, social, and institutional forces and the cognitive dimension of scientific work (Edwards 1996; Foucault 1980; Kay 2000; Shapin and Schaffer 1985).

Contrary to the "standard" view of metaphor in science, which contrasts science with rhetoric and identifies the scientific with the literal or nonmetaphorical, recent studies have suggested that metaphor is constitutive of science (Bono 1990; Leary 1990). Michael Arbib and Mary Hesse have argued that all scientific language is metaphorical: "scientific revolutions are, in fact, metaphoric revolutions, and theoretical explanation should be seen as metaphoric redescription of the domain of phenomena" (Arbib and Hesse 1986, 156). According to Laurence Smith, "scientists can criticize the metaphor systems/metaphysics of other scientists only from the perspective of a metaphor systems/metaphysics of their own. To abandon one system of metaphors/metaphysics is to adopt another" (Smith 1990, 260). Robert Hoffman, Edward Cochran, and James Nead have suggested that "discovery is often the invention of new metaphorical ways of representing things, and choosing between theories is often a matter of choosing between more or less fruitful metaphors" (Hoffman, Cochran, and Nead 1990, 212). Undermining the boundary between the "intrascientific" and the "extrascientific," metaphors illuminate the political and cultural dimensions of scientific discourse (Bono 1990).

This article examines several key shifts in the history of Soviet physiology by tracing the changing meanings of contemporary man-machine metaphors. Cybernetic metaphors entered Soviet academic discourse at a time of sharp group divisions in the physiology community. The scientific utility of machine analogies was closely intertwined with their philosophical and political meanings, and new interpretations of these metaphors emerged as a result of political conflicts and realignment of forces within the scientific community and in society at large. Orthodox followers of Ivan Pavlov's reflex theory vehemently opposed cybernetic analogies. The Pavlovians scorned the very idea of comparing man to a machine and condemned cybernetics as a variety of philosophical mechanicism and an ideological deviation from dialectical materialism, the official Soviet philosophy of science. Cybernetic physiologists, by contrast, argued that it was the Pavlovian conditional reflex theory that degraded the organism, reduced it to a "reactive automaton," and fell under the rubric of "classical mechanicism."

The struggle between the orthodox Pavlovians and the adherents of physiological cybernetics is interpreted here as a conflict between two opposing man-machine metaphors in Soviet physiology. The Pavlovian theory was based on the telephoneswitchboard metaphor of the higher nervous activity; the Pavlovians internalized this metaphor so deeply that they could no longer see its mechanical nature. The cybernetic physiologists, on the other hand, were fascinated with the complexity and subtlety of physiological models mimicking digital computers and feedbackcontrolled servomechanisms. By referring to purposeful behavior which was 
bracketed out by Pavlovian orthodoxy, cybernetic metaphors opened new vistas for research.

While hating their opponents' central machine metaphor, each group at the same time loved their own technological analogy. Although on the surface the Soviet debates over the meaning of cybernetics for physiology always stressed that the organism must not be reduced to a mechanism, Soviet physiology seemed to progress steadily from one man-machine metaphor to another. The constant travel of manmachine analogies back and forth between physiology and technology and the circular modeling of organisms and machines one upon the other not only illuminate the case of "physiological cybernetics," but also throw new light on the history of physiology in general.

\section{The Pavlovian Switchboard Metaphor}

Ivan Petrovich Pavlov (1849-1936) occupied an exceptional place in Soviet science - both as a man and as a symbol (Golikov and Lange 1999; Grigoryan 1999; Joravsky 1989; Todes 2001). He enjoyed great international fame and was named the "leading physiologist of the world" at the Fifteenth International Psychological Congress in 1935. Until the mid-1950s, he remained the only Nobel Laureate among Soviet scientists and constituted a valuable national asset, in both scientific and propaganda terms. Pavlov used his administrative authority as the head of several laboratories and his personal access to Soviet leaders as an expert advisor to the government to advance his ambitious agenda of experimental and theoretical research. After Pavlov's death in 1936, his theory of conditional reflexes was officially canonized and became the dominant conceptual framework for Soviet physiology.

For Pavlov, modern technology was an emblem of sophistication, and he aspired to "elevate" his theory of nervous activity to an equally high level of complexity. Accordingly, his own laboratory at the Imperial Institute of Experimental Medicine in St. Petersburg was organized as a giant "physiology factory" with rigid division of labor, strict discipline among the workforce, uniformity of experimental procedures and results, and a quality check on knowledge claims, which were to conform to the Pavlovian theoretical framework (Todes 2001). Pavlov strove to uncover precise quantitative laws governing physiological processes and insisted on the "complete exclusion of psychic influence" from his experiments so that machine-like regularities underlying the functioning of physiological mechanisms would not be obscured. Viewing the organism as a complex machine, Pavlov modeled his ideal of scientific investigation on engineering practice:

Man is definitely a system (more crudely speaking, a machine), which, like any other system in nature, obeys the inescapable and uniform laws of all nature; but this system, in the horizon of our contemporary scientific view, is unique in its highest degree of selfregulation. Among the products of man's hands, we are already sufficiently familiar with machines that regulate themselves in various ways. From this point of view, the method 
of studying the man-system is the same as for any other system: decomposing into parts, studying the role of each part, studying the connections among the parts, studying the relations with the environment, and finally, based on all this, understanding the overall functioning of this system and, if within human capacity, controlling it. (Pavlov [1932] 1996, 182-83)

In his writings, Pavlov regularly borrowed metaphors from contemporary technology. He called the digestive system a "chemical factory" and compared the nervous system to a central telephone switchboard (Pavlov [1909] 1996, 71; [1927] 1949, 41-42). The latter metaphor illuminated his crucial distinction between conditional and unconditional reflexes. According to Pavlov, inborn unconditional reflexes fixedly tied a particular stimulus (e.g., the viewing of food) to a specific response (e.g., salivation). Pavlov compared such reflexes to a set of direct, permanent telephone lines. Conditional reflexes (e.g., salivation in response to the ringing of a bell, previously associated with the viewing of food) could be acquired, lost, and reestablished. Pavlov likened conditional reflexes to flexible temporary connections between telephone users through a switchboard. "In technology, as in our daily life," he wrote, "the principle of [temporary] connection is applied so often that it would be odd not to expect the implementation of the same principle in the mechanism of the higher nervous system, which establishes most complex, subtle connections" (Pavlov [1927] 1949, 43). In the same way as the central telephone station solved the problem of communication for a large number of users, the mechanism of conditional reflexes, in Pavlov's view, solved the problem of the organism's reaction to diverse stimuli.

Pavlov's work, widely advertised in the Soviet press as an emblem of world-class Soviet science, was propagated far beyond the circle of professional physiologists and became part of popular culture. In 1935 the engineer G. Babat from the Leningrad factory "Svetlana," built an electronic "dog" that imitated Pavlovian reflexes. Pavlov reportedly examined this machine and "endorsed it" (Teplov 1963, 177). Machine metaphors resonated with the Soviet movement for automation and rationalization of labor, which began in the 1920s and thrived during the shock industrialization in the 1930s. In physiology, pervasive machine analogies heavily influenced not only the dominant Pavlovian theory, but also some of the alternative research trends.

\section{"The Machinization of Man"}

In the early Soviet years, new machines, such as tractors and electric generators, were hailed as signs of progress and emblems of the bright communist future (Stites 1989). Man-machine metaphors permeated public discourse; contemporary poetry and popular songs propagated images of "iron men" with "a flaming engine in place of heart." Such man-machine analogies looked elevating. The Soviet fascination with Taylorism and Fordism produced a popular movement for the "scientific organization of labor," led by Aleksey Gastev, a visionary who saw increasing automaticity and 
standardization of workers' movements, language, and even thoughts as means for improving the efficiency of labor (Bailes 1977; Johansson 1983). In 1920, Gastev organized the Central Institute of Labor in Moscow and launched a wide range of scientific studies of efficient labor techniques. These techniques were spread through training courses for some 20,000 instructors and 500,000 workers. In 1924, Gastev wrote:

We start from the most primitive, the most elementary movements and produce the machinization of man himself.... The perfect mastery of a given movement implies the maximum degree of automaticity. If this maximum increases, . . . nervous energy would be freed for new initiating stimuli, and the power of an individual would grow indefinitely. (Quoted in Smetanin et al. 1970, 19; emphasis in original)

The Central Institute of Labor sponsored extensive physiological research based on the conceptual apparatus and experimental techniques of the European science of "biomechanics," which conceptualized the human body as a mechanical system of muscular masses and forces (Rabinbach 1990). Nikolay Aleksandrovich Bernshteyn (1896-1966), the Institute's leading physiologist, conducted a series of experiments that measured the trajectories and speeds of human limbs, while his subjects performed various labor tasks (Demidov 1989; Graham 1987, 192-97; Kozulin 1984; Sirotkina 1995; Whiting 1984). At the foundation of his approach lay a powerful manmachine metaphor. In a 1926 textbook for biomechanics instructors, Bernshteyn wrote:

Biomechanics . . . is a science that studies how the living machine, that is every one of us, is built, how its moving parts are organized, and how they work ... The laws of mechanics are the same everywhere, no matter if they concern a steam locomotive, a lathe, or a human machine. Therefore, we do not have to derive some new, special mechanical laws. We must only compile a description and a characteristic of this living machine in the same way as we would do it for an automobile or a loom. (Bernshteyn [1926] 1997, 462)

Unlike Pavlov, who focused his research on the digestive system and attached primary importance to the central nervous system, Bernshteyn studied locomotion and discovered that peripheral nervous activity played a prominent role in the coordination of movements. His experiments showed that the same labor task was performed differently - with varying tensions of different muscles - at different times. Bernshteyn argued that muscular movements were "constructed" anew each time the task was performed. He suggested that motor activity must be viewed not as a sequence of determined actions (as in the Pavlovian reflex theory), but as a cycle of actions and corrections. In the mid-1930s, he proposed to replace the classic Pavlovian concept of "reflex arc" with a "reflex circle" (Bernshteyn [1934] 1966, 77-78; [1935] 1967, 15-59).

As Bernshteyn's theory differed from Pavlov's, so did their central machine metaphors. Bernshteyn compared the nervous system not to a telephone switch- 
board, as did Pavlov, but to a servomechanism, a feedback-based control device (Kozulin 1984, 65). "The coordination of movements is the elimination of excessive degrees of freedom of a moving organ; in other words, the transformation of this organ into a controllable system," argued Bernshteyn (Bernshteyn [1947] 1997, 51; emphasis in original). The organism achieved such controllability, he argued, via two feedback loops, the peripheral and the central: "A change in muscle tension produces movement, while the movement, by changing the degree of muscle stretch, by shortening or extending the muscles, causes further changes in muscle tension. We call this feedback loop the peripheral cycle of interactions" (Bernshteyn [1940] 1966, 173; emphasis in original). The "central cycle" operated according to the "principle of sensor corrections," based on the same feedback mechanism as implemented in contemporary control devices:

As soon as an organ subjected to various external and reactive forces, as well as to some internal muscle forces, deviates in its resulting movement from the course desired by the central nervous system, the latter would receive exhaustive signals about this deviation, which would be sufficient to introduce adequate corrections in the effector process. (Bernshteyn [1947] 1997, 43)

Challenges to Pavlov's reflex-based conceptual scheme came also from within his physiological school. In the early 1930s, Pëtr Kuz'mich Anokhin (1898-1974), a former researcher in Pavlov's laboratory, proposed to group all physiological processes into a set of functional systems responsible for specific functions, such as breathing, swallowing, or locomotion (Graham 1987, 200-11; Simonov 1990). In a series of experiments, Anokhin cut a dog's nervous channels, intercrossed them, and observed how various centers of nervous activity adapted to the change and restored their functions. In his view, each functional system worked in a closed loop: signals from peripheral organs "sanctioned" those patterns of excitation in the center that caused favorable effects ("sanctioning afferentation") and thus facilitated the restoration of damaged functions. While other Pavlovians emphasized the role of the central nervous system and viewed the cerebral cortex as the sole governing organ, Anokhin shifted the emphasis to the interaction between center and the periphery as a key to understanding physiological processes (1978). Both Anokhin and Bernshteyn proposed new physiological theories based on the idea of feedback, making a major break with Pavlov's open-loop model of "reflex arc." Unfortunately, this proliferation of innovative physiological theories was short-lived.

In the 1930s the Party and the Soviet government began to "mobilize" scientists in the service of socialist construction. They strengthened and centralized their control over Soviet science; the bureaucratic control apparatus began to play a significant role in "appointing" the leading scientists and scientific institutions (Krementsov 1997). By that time, due to Pavlov's authority and influence, his school was already firmly established as the leader of Soviet physiology. Even though Pavlov himself died in 1936, his disciples secured the dominant position for Pavlovian 
physiology in the new, centralized structure of Soviet science. The Pavlovian reflex theory became the undisputable canon for Soviet physiology.

Like many other canons, however, the Pavlovian legacy proved amenable to diverse interpretations. Some of Pavlov's former students laid exclusive claims to his legacy and began to pull Soviet physiology in different directions. An institutional conflict between rival groups within the physiological community took the form of a debate over the correct interpretation of Pavlov's teachings.

At the onset of Cold War the Party launched a series of propaganda campaigns aimed at combating Western ideological influences. Some unscrupulous scientists cleverly turned ideological rhetoric against their scientific opponents and institutional rivals. The infamous Trofim Lysenko secured Stalin's personal backing and viciously attacked Soviet geneticists, accusing them of producing "idealistic," "metaphysical," and ultimately useless theories. Career-minded individuals in other fields of science quickly jumped on the new bandwagon. Following Lysenko's triumph at the JulyAugust 1948 session of the Lenin All-Union Academy of Agricultural Sciences, an ideological campaign against "reactionary" and "idealistic" science swept all scientific disciplines, including physiology. Campaign activists cleverly tied Pavlov's teachings to Lysenko's doctrine, which now had the stamp of official approval. Despite Pavlov's well-known personal support of genetic research in the 1930s and even his order to erect a monument to Gregor Mendel in front of his laboratory, some of his former students now claimed full compatibility of Pavlov's teachings with Lysenkoism. They revived Pavlov's early hypothesis (which he had later rejected) about the inheritance of conditional reflexes and their transformation into unconditional ones, and linked it with Lysenko's central dogma of the inheritance of acquired traits. In 1950, they convened a special joint session of the Academy of Sciences and the Academy of Medical Sciences in Moscow to solidify their reinterpretation of Pavlov's legacy and to purge their opponents. Several prominent physiologists who resisted this dogmatic interpretation were accused of the "perversion of Pavlov's line" and dismissed from their jobs, and this opened wonderful career opportunities for orthodox Pavlovians (Krementsov 1997, 260-75). Bernshteyn, one of the most vocal opponents of reflex theory, was accused of "idealism" (for using mathematical analysis) and was charged with knowing "neither the letter nor the spirit of Pavlov's teachings" (quoted in Sirotkina 1995, 31). Such criticism amounted to political denunciation, and Bernshteyn was soon forced out of his job and lost any opportunity for research and publication. Anokhin, who initially had been actively involved in the preparation of this session, was outmaneuvered by his rivals and lost his position as well. The name Pavlov now stood for Party-blessed dogma in science.

\section{Cybernetic Metaphors: The Servomechanism and the Computer}

While in the Soviet Union feedback-based physiological models emerged in opposition to Pavlov's reflex theory, Western cyberneticians, ironically, saw Pavlovian physiology as fully compatible with cybernetics. Norbert Wiener called Pavlov a 
"great scholar" (Wiener [1950] 1967, 93) and regarded reflex theory as an important source for his cybernetic studies. In particular, Wiener argued that the feedback mechanism could explain Pavlovian conditional reflexes. He called a physiological analog to the feedback signal "affective tone":

An increase in affective tone favors all processes in a nervous system that are under way at the time and gives them a secondary power to increase affective tone; and ... a decrease in affective tone tends to inhibit all processes under way at the time and gives them a secondary ability to decrease affective tone. . . Note that the mechanism of affective tone is itself a feedback mechanism. (Wiener [1948] 1961, 128)

Wiener suggested that conditional reflexes could operate according to the same mechanism. He drew a direct analogy between reflexes and the performance of the anti-aircraft predictor that he designed during World War II. In both cases, he argued, "anticipatory feedback" was involved, which included an effector with a lagging characteristic and a compensator that acted as a predictor. Such anticipatory feedback, he argued, could be "certainly found in human and animal reflexes" (ibid., 113).

Wiener's seminal book Cybernetics, or Control and Communication in the Animal and the Machine (1948) synthesized diverse ideas circulating in the "cybernetics circle" and presented an assembly of appealing analogies between living organisms and selfregulating machines, such as feedback-controlled servomechanisms and stored-program computers: the body as a feedback-operated servomechanism, life as an entropy-reducing process, man as an "information source," human communication as transmission of encoded messages, the human brain as a network of logical elements, and the human mind as a digital computer. Drawing on the similarity between mathematical techniques of control engineering (tracking and targeting) and communication engineering (noise reduction), Wiener suggested a fundamental affinity between control and communication: both used the same mechanism of negative feedback. In cybernetics, information was defined as "negative entropy" and interpreted as a measure of order, organization, and certainty, while entropy was associated with chaos, noise, and uncertainty; physiological homeostasis was compared to physical equilibrium; neurons were treated as logical elements; and thinking was made synonymous with computation (Edwards 1996; Gerovitch 2002; Heims 1980; Mindell 1996).

Wiener aspired to integrate contemporary developments in control engineering, communication engineering, computing, physiology, thermodynamics, and social science and to produce a unified theory of cybernetic systems. His strategy for tying together diverse mathematical models, explanatory frameworks, and appealing metaphors from these disciplines was to create a common language. Wiener drew concepts from computing (algorithm), physiology (adaptation, homeostasis, and reflex), psychology (behavior, learning, and memory), control engineering (control and feedback), thermodynamics (entropy and order), and communication engineering (information, signal, and noise) and generalized them, attaching new, broader 
meanings that crossed the border between the animate and the inanimate. Neglecting the differences between maintaining equilibrium and reaching a goal or between conversation and information transfer, Wiener argued that this new language was equally applicable to all cybernetic systems, including living organisms, self-regulating machines, and human society. The cybernetic language effectively erased the boundary between people and machines: purposeful human behavior was now explained in mechanical terms as governed by feedback, while the functioning of self-regulating machines was described in anthropomorphic terms as "goal-directed." In his writings, Wiener habitually referred to "those living machines which we call animals" (Wiener [1948] 1961, xiv-xv) and regarded both men and machines as "communicative organisms" (Wiener [1950] 1967, 185). He believed that cybernetics bridged the fundamental gap between mechanical causality and teleological explanation: the same feedback mechanism could now explain both the operation of machinery and human action.

The cybernetic man-machine metaphors gave rise to a host of new neurophysiological theories. The neuroscientist Karl Pribram has argued, in particular, that borrowing models from control engineering helped overcome crucial deficiencies of the Pavlovian telephone switchboard model:

No longer could the organism and its brain be thought of as a passive switchboard on which environmental contingencies might play at will. A new, active image of a selfsetting, homeostatically controlled organism that searched for and selectively accepted environmental events replaced the old passive stimulus-response image. (Pribram 1990, 84)

The homeostatic model of the brain had its limitations, however, since equilibriumoriented neural structures changed very slowly and seemed unable to learn. Another analogy - the McCulloch-Pitts model of the nervous system as a communication network with limited capacity channels - helped establish the level of organization in the brain beyond that of electrical nerve impulses, but it faced its own difficulties. The concept of channel capacity, Pribram has noted, was "an oversimplification in brain science, because fixed channels of limited capacity do not exist in the brain" (ibid., 81). This model subsequently gave way to a yet more flexible computer analogy: "The move from a concept of a restricted channel capacity to the concept of a flexible competency capable of being 'reprogrammed' to meet changing conditions heralds a shift from viewing the brain as a telephone-like system to regarding it as computerlike" (ibid.).

In the 1950s and 1960s, cybernetic models and analogies gained huge popularity in the West and spread across a wide spectrum of disciplines, from physiology to psychology to genetics to psychiatry to sociology to economics to linguistics (Edwards 1996; Heims 1993). For example, in psychology and genetics, both thought and heredity were described as "information processing"; both the brain and the genome were seen as "computers"; both cognitive and genetic processes were said to 
be "preprogrammed"; both memory and genome were thought to contain encoded information; both learning and biological development were described as "selforganizing" processes; and both consciousness and genetic regulation were viewed as "feedback" phenomena (Boyd 1993, 360; Kay 2000, 24-25).

Cybernetic ideas not only affected conceptual trends in various scientific disciplines, but also had extensive political and cultural ramifications. Several authors have traced the origins of key cybernetic concepts to Wiener's work on anti-aircraft fire control during World War II and argued that cybernetics embodied distinct military patterns of control and communication (Edwards 1996; Galison 1994; Hughes and Hughes 2000; Mirowski 1991; Pickering 1995). Reified in military command-and-control systems, cybernetic ideas rendered support to the vision of the political and social world as a closed, computable system subject to manipulation and control. By making the military conflict a model for our interaction with the world, the cybernetic discourse effectively circumscribed alternative forms of knowledge and reinforced ideological stereotypes of the Cold War. At the same time, the cultural image of a cyborg - a cybernetic organism, a hybrid of machine and organism, an "illegitimate offspring" of militarism and capitalism - proved "exceedingly unfaithful" to its origins (Haraway 1991, 151). Like a "floating signifier," it crossed cultural boundaries, undermining the accepted dichotomies between "mind and body, animal and human, organism and machine, public and private, nature and culture, men and women, primitive and civilized" (ibid., 163).

Traveling through different political and cultural contexts, cybernetic manmachine metaphors acquired, lost, and reacquired diverse and contradictory meanings. In the early 1950s, while the Western popular press hailed Wiener as the "prophet of the second industrial revolution" and promoted digital computers as "electronic brains," in the Soviet Union cybernetic ideas obtained quite different political and cultural connotations.

\section{From Cybernetic Mechanisms to Philosophical Mechanicism}

The early 1950 s - the time when Soviet readers first learned about cybernetics - was the wrong time to propagate in the Soviet Union ideas that originated in the West. This applied not only to political doctrines, but also to scientific theories. On the wave of Cold War propaganda, Party-minded scientists, journalists, philosophers, and sociologists ("soldiers of the ideological front") were looking for examples of "reactionary" Western scientific theories. They routinely attached to such theories philosophical labels with negative ideological overtones: "idealism" (replacing reality with mathematical formulas and abstract concepts), "mechanicism" (reducing complex laws of nature and society to mechanical causality), "metaphysics" (denying a dialectical sense of development), and "formalism" (reducing the essence of phenomena to their form). In various combinations, these clichés were applied to quantum mechanics, relativity theory, genetics, the theory of chemical resonance, 
structural linguistics, and many other theories (Gerovitch 2002; Graham 1987; Vucinich 1984). Any Western-born scientific theory was a potential victim. Cybernetics, with its far-reaching and broadly-interpreted man-machine metaphors, presented a particularly convenient target.

In the early 1950s nearly a dozen sharply critical articles appeared in Soviet academic journals and popular periodicals, portraying cybernetics as an exemplary product of American imperialist ideology and accusing Western cyberneticians of a whole assortment of ideological sins. More interested in fulfilling their quota of ideological criticism than in serious analysis of the content and philosophical ramifications of cybernetic works, Soviet critics erected a philosophical strawman, whom they then thoroughly destroyed (Gerovitch 2001b).

"Soldiers of the ideological front" gradually shaped a negative ideological image of Western cybernetics according to the standard repertoire of propaganda clichés. They portrayed cybernetic man-machine analogies as attempts to equate men with machines, and defined cybernetics as "a form of modern mechanicism" (Anonymous 1954, 236). They charged that cybernetics committed a grave philosophical error by reducing the natural laws governing biological, psychological, and social processes to physical or simply mechanical laws. One critic argued that cyberneticians "transfer all the activity of their brain to a mechanical connection and to signalling" and they therefore "throw science back two hundred years" to La Mettrie's concept of l'homme machine (Materialist [1953] 1974, 37). Playing with the words "mechanical" and "mechanistic," another author wrote: "On the basis of mechanistic principles, in the United States recently emerged a pseudo-science of cybernetics, which promises to build perfect mechanical robots" (Medvedev 1954, 105-106). A third critic maintained that "no mechanical model can be equated with any biological process, especially with higher nervous activity" (Bykhovskiy 1952, 126). The same critic also claimed that cyberneticians reduced biological and sociological laws to "pure" mathematical formulas and equations, which opened a way to "idealistic speculations" (Bykhovskiy 1953, 44).

What exactly constituted a mechanistic or an idealistic deviation from dialectical materialism, the official Soviet philosophy of science, was by no means clear. In physics, for example, some scientists and philosophers identified the dialectical materialist standpoint with classical mechanics, while others claimed full compatibility of dialectical materialism with quantum mechanics (Graham 1987). Drawing a line between knowledge and ideology, between the "objective core" of a scientific theory and its "philosophical interpretation," was also a matter of fierce debate (Gerovitch 2001a). Despite their discursive elasticity, deviations from dialectical materialism were portrayed not merely as philosophical errors, but as serious ideological or even political mistakes. Cybernetics was thus depicted as a pseudoscientific theory, a false philosophy, and an alien ideology at the same time.

Like any ideological discourse assembled from prefabricated components, the anticybernetics campaign was insensitive to its inner contradictions. Cybernetics was portrayed both as "idealistic" and "mechanistic," as "utopian" and "dystopian," as 
"technocratic" and "pessimistic," and as a "pseudo-science" and a blueprint for dangerous weapons. Producing a typical oxymoron, the critics branded cybernetics "not only an ideological weapon of imperialist reaction but also a tool for accomplishing its aggressive military plans," referring to the use of computers and servomechanisms in the construction of remotely controlled, automated, electronic weapons (Anonymous 1954, 237). It was not entirely clear how a worthless pseudoscience - an expression of obscurantist, reactionary ideology - could assist in the construction of working weapons. To enlarge the significance of cybernetics as a formidable ideological enemy, the critics gave it credit for all military applications of computing and control engineering in the West. True, cybernetics was informed by wartime research projects and embodied some elements of military thinking, patterns of encoded communication, and principles of command and control. Yet cybernetics for Wiener and his associates was a civilian enterprise; their cybernetic ideas largely affected the life sciences and the social sciences, while the military benefited mostly from Wiener's earlier mathematical work. Cybernetics could be seen, therefore, as a product, rather than a driving force, of American military research on control and communication. Soviet critics also ignored, or perhaps were not aware of, Wiener's open pacifist stand, which he had taken after Hiroshima.

In their zealous pursuit of ideological enemies, the critics totally ignored the long tradition of man-machine analogies in Russian and Soviet physiology. While Wiener viewed cybernetics as a legitimate heir to the Pavlovian tradition, the critics portrayed the two as irreconcilable opponents. They charged that the cyberneticians aspired to replace physiology with mechanics and the Pavlovian concepts of conditional and unconditional reflexes with the notion of feedback (Gladkov 1955, 61). The French Marxist journal La Pensée called cybernetics a "weapon of the Cold War against Pavlov" (Lentin 1953, 60), and Soviet authors readily quoted this epithet. The critic writing under the pseudonym Materialist portrayed cybernetics as a deliberate attack on Pavlov's doctrine:

The most progressive teaching of contemporary natural knowledge confronts the rabid opposition of the reactionaries of science. Since they are not in a position to find scientific arguments against the teaching of I. P. Pavlov, they are left with the path of falsification and distortion of this teaching. Unequivocally, they endow the computer with properties of the central nervous system . ... Nevertheless, it is only a mechanism, operated by acoustic, light, and mechanical signals, and it has nothing in common with the reflexes of a man. (Materialist [1953] 1974, 38)

In support of his argument, Materialist cited Pavlov: "on our planet, the nervous system is inexpressibly the most complex and delicate instrument of relations and connections among the numerous parts of an organism and between an organism as a most complex system and an infinite number of external influences." As it turned out, the critic skillfully cut out this quotation from the middle of a paragraph to hide the evidence of Pavlov's own fascination with machine metaphors. Right before these 
words, Pavlov had written: "Thus, in the central nervous system two different central apparatuses are present: one that conducts the nervous current and one that connects and disconnects it." Right after the words cited by the critic, Pavlov had mused: "When the connecting and disconnecting of electric circuits is now our daily technical device, can anyone really object to the implementation of the same principle in relation to this amazing instrument [i.e., the nervous system]?" (Pavlov [1936] 1996, 245).

During the anti-cybernetics campaign the name Pavlov was regularly evoked to condemn any parallels between men and machines. The Short Philosophical Dictionary alleged that cybernetics had put an equals sign between the human brain and the calculating machine and therefore cybernetics had been "in essence directed against modern scientific physiology, firmly established by I. P. Pavlov" (Anonymous 1954, 237). One critic alleged that cybernetics was based on a "mechanistic conception of higher nervous activity" and was directed against Pavlov's "teaching of genius." "Whereas the principles discovered and comprehensively studied by I. P. Pavlov are based on the dialectical understanding of higher nervous activity and on the study of the brain as an organ functioning as a whole," this critic wrote, cyberneticians "regard the brain as an aggregate, a mechanical assembly of cells" (Bykhovskiy 1952, 125; emphasis in original). He concluded that cyberneticians reduced the human being to the status of a "talking machine" (Bykhovskiy 1953, 44).

Trying to combine patriotic rhetoric promoted by the Party during World War II with the new ideological stereotypes of the Cold War, Soviet authors often dismissed Western-born cybernetics as reactionary nonsense and, in the same breath, claimed national priority in elaborating the very same ideas. Pëtr Anokhin, when asked to review an article on cybernetics written by two computer specialists for The Literary Gazette, joined in the authors' condemnation of the cybernetic analogy between the human brain and automatic control devices. He wrote that the two authors were "absolutely justified" in calling this analogy "methodologically harmful," "based on a reactionary scheme," and "aimed at reducing the human being involved in sociallyminded activity to the status of a mechanical automaton, a 'robot'" (Anokhin n.d., 1. 139). At the same time, Anokhin proudly noted that cyclical regulatory mechanisms and the idea of feedback had already been thoroughly studied in the Russian school of physiology, particularly, by the nineteenth-century physiologist Ivan Sechenov. Anokhin was cautious, however, not to attract attention to his own use of feedback models back in the 1930s. He fully dissociated himself from the ideologically suspect cybernetics and condemned cyberneticians' attempts to apply feedback models to the complex phenomena of higher nervous activity "in a crude mechanistic fashion." Pavlov's doctrine, he affirmed, was "absolutely incompatible with the mechanistic ideas of this absurd "teaching." "Anokhin concluded that cybernetics "stands on a flawed methodological foundation, contains a whole series of illiterate neurological assumptions and speculations, and serves the reactionary goals of the capitalist society" (ibid., 1. 140). Not surprisingly, when a group of Soviet psychologists 
attended the XIV International Congress of Psychology in Montreal in 1954, their report listed the use of computers in psychological research among the topics that "had no principal significance" (Leont'ev et al. 1954, 1. 128).

\section{"Man is the most perfect of all known cybernetic machines ..."}

In October 1955, the world learned what Western specialists had long suspected: the Soviet delegation at the Conference on Electronic Digital Computers and Information Processing in Darmstadt, West Germany, announced for the first time that the Soviet Union had built several high-speed electronic digital computers and disclosed some of their technical parameters. A flurry of articles appeared in Soviet newspapers, magazines, and scholarly journals, popularizing this new magic tool for solving hitherto unsolvable problems. Although the first computer applications were almost exclusively military - the design of the hydrogen bomb and the calculation of intercontinental ballistic missiles' trajectories - the public image of the computer promised a complete transformation of science, technology, and daily life. No limit to the power of computers was in view; it seemed that they would be able to solve any problem, if only it was formulated in the right language - the language of computer algorithms.

The computer arrived at the scene at the time of a major political upheaval in the Soviet Union. Nikita Khrushchev's condemnation of Stalin's “cult of personality" at the Twentieth Party Congress in February 1956 started a new era of Soviet history. The ensuing political "Thaw" brought significant changes to all spheres of Soviet life. In particular, the period of forced isolation of Soviet science from its Western counterpart came to an end: information floodgates were open, and some Soviet scientists were also allowed to go abroad. A direct comparison made the gap between the developed countries and the Soviet Union in a number of fields that had been booming in previous years, such as genetics or semiconductor technology, so conspicuous that it could no longer be ignored. The ideological attacks on "reactionary" Western science in the spirit of Lysenko were seriously curtailed; Party and government authorities embarked on a course of rapid assimilation of modern Western scientific and technological advances (Medvedev 1978, 58-102; Vucinich 1984, 257-313). Catching up with the West in digital computing became one of the top priorities.

The new generation distinguished itself by its language, fresh and bold in its attempt to cleanse itself of Stalinist ideological clichés and obtrusive rhetoric. Many Soviet intellectuals saw in the language of science, particularly mathematics, the sought-after "language of truth." As the Russian cultural historians Pëtr Vayl' and Aleksandr Genis have metaphorically put it, "when it turned out that words lied, formulas looked more trustworthy"; "exact knowledge seemed an equivalent of moral truth; an equals sign was put between honesty and mathematics" (Vayl' and Genis 1996, 100). 
The computer embodied this new spirit of rigorous thinking, logical clarity, and quantitative precision; it became an emblem of objectivity, a reified opposition to Stalinist manipulative ideological discourse. Computers set a moral example of how to withstand outside pressure and hold to the truth. Nikolay Bernshteyn, who was able to return to active research during the "Thaw," publicly proclaimed that computer models provided "a demanding and unyielding criterion" of truth:

In human thinking, there is always certain unconscious arbitrariness, and as a result, an author's ardent belief may prompt him to take the desired for real. But a model presented as a program for digital computer or as an electronic analog device would not yield to any attempts to persuade it or to make it change its mind with regard to something incompatible with its structure. The model works strictly in accordance with the objective laws of nature and the equally firmly established laws of mathematics. (Quoted in Parin et al. 1969, 124; emphasis in original)

The image of an objective, truth-telling computer became a vehicle for the emerging Soviet cybernetic discourse. Expanding Wiener's understanding of cybernetics to encompass all potential computer applications, Soviet cyberneticians viewed their discipline as a science of computer algorithms, a theoretical and practical guide for converting scientific knowledge into computer models and testing its validity (Gerovitch 2000; Gerovitch 2002; Graham 1987, 266-93; Holloway 1974). Speaking at a session of the Soviet Academy of Sciences in October 1956, the leading Soviet cybernetician Aleksey Lyapunov of the Division of Applied Mathematics outlined an ambitious program of the "algorithmization" of various spheres of science and technology:

The algorithmization of technological processes is required for production control; the algorithmization of linguistic processes is required for the implementation of machine translation. To transfer a wide range of human functions to a machine, the algorithmic modeling of the functions of thought and behavior is required, and here cybernetics borders upon biology and psychology. (Keldysh, Lyapunov, and Shura-Bura 1957, 129)

The October session was devoted to the promotion of industrial automation, in which cybernetics was assigned a central role. Articles propagandizing cybernetics began to appear in popular press; books, including translations of Wiener's works, soon followed.

Capitalizing on new political and technological trends, Soviet cybernetics enthusiasts quickly cleared their discipline of any previous ideological charges. Speaking at the All-Union Conference on Philosophical Problems of Natural Science in October 1958, Lyapunov's close ally, the prominent mathematician Sergey Sobolev of the Institute of Atomic Energy, brushed aside the philosophical critique of cybernetics as totally irrelevant. "Cybernetics is neither mechanistic, nor idealistic," he said. "It is first and foremost a science of facts. There can be no idealistic or 
materialistic facts; a fact is always a fact. Cybernetics, a science of control systems, studies facts that exist in reality, and it would be outlandish to call cybernetics an 'idealistic science"' (quoted in Kirillin and Frolov 1958, 162). Sobolev did not use any philosophical arguments to refute the charge of idealism; instead, he claimed that philosophical terminology simply was not applicable to cybernetics. The conference effectively stripped Soviet philosophers of their former authority to judge scientific controversies (Fedoseyev 1959).

Cybernetics enthusiasts put forward an ambitious program of "cybernetization" of a wide range of scientific disciplines, including physiology. Sobolev, in particular, made it absolutely clear that cybernetics would take over the subject of physiology:

In cybernetics, a machine is defined as a system capable of accomplishing actions that lead to a certain goal. Therefore, all living organisms, and human beings in particular, are in this sense machines. Man is the most perfect of all known cybernetic machines .... There is no doubt that all human activity manifests the functioning of a mechanism, which in all its parts obeys the same laws of mathematics, physics, and chemistry, as does any machine. (Sobolev 1963, 83)

Lyapunov and his associates formulated the following tasks for "physiological cybernetics":

(1) the study of information flows in the nervous system and the receptors;

(2) the study of the methods of encoding information in the nervous system and the receptors;

(3) the study of reactions, reflexes, and behavior of animals;

(4) the evaluation of the amount of information and the channel capacity of the nervous system;

(5) the study of hierarchical functioning and collective behavior;

(6) the algorithmic description of the nervous system and the receptors. (Lyapunov and Yablonskiy [1963] 1980)

To set an example of successful translation of physiological concepts into the language of cybernetics, Lyapunov offered a stochastic algorithm modeling the acquisition of a conditional reflex (Lyapunov [1958] 1980, 68-69).

Since Soviet physiology at that time was effectively reduced to Pavlov's reflex theory, the first attempts to extend cybernetic reasoning into physiology focused on modeling reflexes. Cybernetics enthusiasts argued that modern automatic control devices were already capable of demonstrating unconditional reflexes (in terms of giving preset responses to diverse inputs), and they insisted that conditional reflexes could also in principle be reproduced. "Taking the exact sense of Pavlov's definition [of the conditional reflex]," wrote the control engineer I. I. Gal'perin, "it is impossible to make a distinction between the mechanism of the conditional reflex and the functioning of an automatic control system" (Gal'perin 1957, 159). He claimed that "automatic control systems in today's machines fulfill the function of a 
nervous system" (ibid., 162) and announced that automatic control devices brought about a "reevaluation of physiological values" (ibid., 167).

Paraphrasing Pavlov's contention that the human brain, which had created natural science, was itself becoming a subject of natural science, Gal'perin wrote: "The human brain, which has created technology, now, in control devices, is itself becoming (in its simplest functions) a subject of technology" (ibid., 168). If the human brain was becoming a subject of technology, what would be the subject of neurophysiology? This cybernetic "expansionism" left little room for non-cybernetic physiology.

\section{Bernshteyn's "Physiology of Activity"}

The new political climate and major institutional transformations of Soviet science under Khrushchev gave many Soviet scientists who had been marginalized under the dominance of Stalinist schools an opportunity to legitimize and institutionalize their research. In 1957, a separate interdisciplinary Siberian Division of the Academy was established, with the center in Akademgorodok, the Science City near Novosibirsk (Josephson 1997). In 1961 and 1963, two major reorganizations of the Academy created a number of new divisions and considerably weakened the positions of the Stalinist guard (Adams 1977-78). For example, genetic research was conducted not in biological institutions (which were controlled by the Lysenkoites) but under the roofs of physical and chemical research institutes. Genetics "hid under protective language: to cognoscenti, such terms as 'radio-biology,' 'radiation bio-physics', and 'physicochemical biology' functioned as a kind of protective mimicry, serving as euphemisms for both orthodox genetics and molecular biology" (ibid., 55). In 1959, the Academy set up the Scientific Council on Cybernetics, chaired by the powerful administrator, Engineer Admiral Aksel' Berg, a former deputy minister of defense (Gerovitch 2000). The Council on Cybernetics served as an institutional "umbrella" for a wide range of previously marginalized research trends: genetics ("biological cybernetics"), structural linguistics ("cybernetic linguistics"), new approaches in chemical experiment planning ("chemical cybernetics"), and non-Pavlovian physiology ("physiological cybernetics"). With the Council's support, unorthodox researchers were able to publish their papers, convene conferences, and effectively legitimize their work as part of a unified national plan of cybernetic research (Gillespie 1974).

Seeing in the rise of cybernetics a unique opportunity to revitalize his original research program, Nikolay Bernshteyn translated his theory of locomotion into the cybernetic language. Instead of the "construction of movements," he began to speak of "control" and "programming"; nervous impulses became "informations" (plural); and the motor apparatus was described as a self-regulating servomechanism (Bernshteyn [1957] 1967, 131). Bernshteyn fully explored the cybernetic analogies with feedback-controlled servomechanisms and stored-program computers and eventually arrived at a comprehensive model of the organism as a self-regulating 
machine that received information from the external world, encoded it in a model, programmed its actions, and constructed its movements (Bernshteyn [1962] 1969). The use of the cybernetic language made it possible to challenge the Pavlovian school and at the same time to avoid accusations of "idealism" and "vitalism" such as had been brought against Bernshteyn before.

Bernshteyn contended that it was not cybernetics, but rather the Pavlovian reflex theory that was guilty of mechanistic reductionism. He argued that Pavlov's doctrine conceptually belonged to the nineteenth century; the "physiology of the classical period," he claimed, was "largely the product of mechanistic materialism" (Bernshteyn [1963] 1997, 431). According to Bernshteyn, classical physiologists viewed the organism merely as a "highly organized reacting machine" (ibid., 433) and believed that "the whole is always the sum of its parts and nothing more .... Every perception is the sum of elementary sensations, and every integral purposeful reaction of a living organism is likewise the sum of elementary reflexes" (Bernshteyn [1960] 1997, 373). He argued that the rigid Pavlovian scheme of conditional reflexes was based on experimental studies of animals confined in cages and subjected to measured stimuli. "The organism's vital activity and behavior were treated as assemblies or chance sequences of reflexes," he wrote. "The reflex arc inevitably provoked the concept of a living organism as some sort of reacting machine that responded to receptor signals and stimuli” (Bernshteyn [1962] 1969, 443-44).

While the Pavlovian school eschewed the notion of purpose, considering it purely psychological and therefore "unscientific," Bernshteyn made this notion the centerpiece of his theory. ${ }^{2}$ He called for the creation of "physiology of activity," which would study purposeful behavior. He insisted that a scientific physiological study of purposeful behavior was possible if the notion of purpose was conceptualized in cybernetic terms as "material codes in the central nervous system ... such that both forecasts and programs of the future may be programmed into the nervous system" (ibid., 448).

Although Bernshteyn borrowed his new vocabulary from Wiener's Cybernetics, he profoundly reinterpreted cybernetic models and metaphors to fit his own conceptual framework. Bernshteyn found Wiener's model of purposeful behavior motivating, but he revised it immediately. Bernshteyn contended that the goal of action was encoded in the nervous system as the model of a future event, and that purposeful behavior was oriented toward this model, rather than toward an actual goal. For example, in the case of a hand reaching for an object, the feedback-controlled coordination of movements was aimed at minimizing the current deviation from the planned path, rather than the current distance between the hand and the object, as Wiener and Rosenblueth had suggested (Bernshteyn [1957] 1967, 129-30).

\footnotetext{
${ }^{2}$ In 1916, Pavlov delivered a public lecture on the "reflex of purpose." He interpreted purposeful behavior as a form of collecting (the goal of educated people, he said, was to collect knowledge) and ultimately reduced it to the "grasping reflex" (Pavlov [1916] 1928, 275). Pavlov never returned to this topic again (Anokhin [1962] 1978, 292).
} 
Bernshteyn further amended Wiener's model by introducing a clear distinction between simple adaptation to the environment and purposeful activity aimed at changing the environment. While the former could be achieved by means of Pavlovian reflexes, the latter could not be reduced to reflexes. To explain this distinction, Bernshteyn employed the conceptual apparatus of "well-organized functions" elaborated by his close friend, the mathematician Mikhail Tsetlin, and the mathematician Izrail' Gel'fand of the Division of Applied Mathematics. Tsetlin and Gel'fand called multi-variable functions "well-organized" if their arguments could be separated into "essential" and "non-essential" variables. The former determined the main characteristics of a function (its overall shape and its extremes); the latter could cause abrupt local changes and discontinuities but exerted little influence on the function as a whole. Bernshteyn argued that the coordination of movements (for example, writing) and the construction of models in the brain in the process of perception could both be described by those "remarkable functions." A handwriting style, for instance, could vary in its "non-essential" parameters depending on the position of a hand, but it still possessed "essential" features characteristic of a particular person. Bernshteyn argued that living organisms acted just like "well-organized" mathematical functions:

It has already been observed how differently an organism behaves under the influence of its surroundings with reference to essential and non-essential variables. As regards the latter type, it is reactive and, so to speak, yieldingly adaptable: if one leaf on a tree receives more food than another, then that leaf grows more vigorously than the other one .... But essential characteristics of structure and shape ... are only relinquished by an organism if it is subjected to very violent interference... Thus the function, that is the organism, may be said to be reactive as far as its non-essential variables are concerned, but highly non-reactive, or active, with regard to its essential ones. (Bernshteyn [1962] 1967, 178)

By this distinction, Bernshteyn also illustrated the limited applicability of the Pavlovian model (reactions of a passive organism) relative to his own model (actions of an active organism).

While Wiener considered homeostasis a quintessential cybernetic process, Bernshteyn viewed it as a concept from the pre-cybernetic past. An organism's "striving for conquest," Bernshteyn argued, "is not directed toward maintaining status or homeostasis, but toward an unceasing advance in the direction of the inborn program for development and security" (Bernshteyn [1962] 1969, 448). In his model, such concepts as equilibrium and homeostasis were applicable only to non-essential variables. When, on the other hand, external influences affected an organism's essential variables, the organism would "respond with the most active counteraction and not yield without serious struggle, sometimes with the help of a counterforce, sometimes with evasive tactics" (Bernshteyn 1962, 62). Somewhere between the lines, Bernshteyn may have reflected here on the passive social tactics of the 
conformists who were "yieldingly adaptable" and looked for an "equilibrium" with the authorities. Personally, Bernshteyn saw his mission as "liberating the organism from the role of a 'reactive automaton"” (Bernshteyn [1963] 1997, 457) - in other words, liberating Soviet physiology from Pavlovian dogmas.

Cyberneticians provided crucial support for Bernshteyn's position. By the early 1960s, they no longer tried to find cybernetic models most suitable for the Pavlovian theory, but instead shifted their efforts to serious criticism of reflex theory from a cybernetic viewpoint. Speaking at the All-Union Conference on Philosophical Questions of the Physiology of Higher Nervous Activity and Psychology in Moscow in May 1962, the mathematician Mikhail Bongard of the Institute of Biophysics announced that from now on cybernetic models would be "unrelenting examiners" of physiological theories and hypotheses. He contended that Pavlovian reflex theory, if subjected to a cybernetic test, failed to explain pivotal neurophysiological mechanisms, such as learning:

If you claim that you understand the mechanism of learning, this can easily be checked. Engineers will create elements that would be able to acquire conditional reflexes. Try to assemble from such elements a device that would act expediently in a complex changing environment. I have studied this problem myself and learned that it is hopeless to try to assemble such a device from the elements modeling conditional reflexes. (Fedoseyev 1963, 672)

Bongard argued that reflex theory was clearly inadequate for explaining higher nervous activity. According to the Pavlovian doctrine, a conditional reflex can be established only on the basis of an unconditional one, by means of substituting an unconditional stimulus with a conditional stimulus. Bongard contended, however, that complex reactions, such as solving an arithmetical problem, could not be caused by any unconditional stimulus, and therefore there was nothing to substitute for. "Even a system of very complex conditional reflexes would not suffice to explain the activity of a living organism," he maintained, "in the same way as statics cannot explain the flight of a rocket" (ibid.). Instead, Bongard argued, one must look for a solution by building cybernetic models. He suggested a feedback model of learning, implemented in his original computer program for pattern recognition; this program derived its own rules of classification by "learning" from existing examples of correct classification (Bongard 1970).

The reversibility of man-machine metaphors facilitated an exchange of ideas between cybernetic physiology, engineering, and mathematics. Bernshteyn wrote, for example, that an organism encountering a "dynamically variable" situation would have to make "a probabilistic forecast": "To use a metaphor, we might say that the organism is constantly playing a game with its environment, a game where the rules are not defined and the moves planned by the opponent are not known" (Bernshteyn [1962] 1967, 173). His close friend, Mikhail Tsetlin, translated this idea into the 
language of game theory. ${ }^{3}$ He studied a particular type of game, in which stochastic automata did not "know" the pay function of their game in advance and had to develop their tactics in the course of the game. Tsetlin informally compared the tactics of a simple automaton facing complex environment to the behavior of "a little animal in the big world" (Tsetlin 1973, 132).

Tsetlin developed a number of original cybernetic models of physiological processes (Ivanov 1998). He proposed a general mechanism by which the combined action of a large number of primitive automata, each following very simple rules, resulted in expedient actions of the system as a whole. The key to this mechanism, he argued, was in "the principle of least interaction": all parts of the system "strove" to minimize their interaction with other parts and with the system's environment. The actions of each part no longer had to be directed from one center. Given a "pay function," individual automata figured out their own best strategies, which resulted in the overall optimal strategy for the system. Neurophysiologists usually assumed that various nervous centers in the brain coordinated their activity by means of a complex system of connections. Tsetlin argued that, overall, expedient behavior could be achieved even if these centers "interacted" only by means of observing changes in their environment:

At each moment, the subsystem solves its own "particular," "personal" problem - namely, it minimizes its interaction with the medium; therefore, the complexity of the subsystem does not depend on the complexity of the entire system . . . . our mathematical models allow us (to a certain degree) to imagine the interaction of the nerve centers without considering the complex system of links and the coordination of their activity. (Tsetlin 1973, 150-152)

The works of Tsetlin and Bernshteyn straddled the fence between mathematics and neurophysiology. They did not easily fit into the accepted frameworks for either discipline. They found a niche in "physiological cybernetics." Tsetlin became the first "Learned Secretary" of the Council on Cybernetics on the day of its inception. Both Tsetlin and Bernshteyn actively published their results in Problems of Cybernetics, edited by Lyapunov.

Legitimized as "physiological cybernetics," Bernshteyn's methods of the study of locomotion were widely applied in ergonomic studies and in the training of cosmonauts. For example, using Bernshteyn's methods, his student Levan Chkhaidze worked out a quantitative measure of the coordination of motor actions and was able to prove that this coordination would be quickly restored after some initial disturbance caused by changes in the gravitational field (Chkhaidze 1965). In 1967 a collection of Bernshteyn's articles was translated into English and propagandized by

\footnotetext{
${ }^{3}$ The mathematician John von Neumann developed basic principles of game theory in the late 1920s; in the late 1940s, he and the economist Oscar Morgenstern generalized this theory to describe economic behavior (Mirowski 1992). In the Soviet Union, game theory was considered part of cybernetics.
} 
a group of physiologists at Haskins Laboratories in New Haven, Connecticut. His work "rapidly became a sort of bible for those who considered him as a laboratory genius"” (Requin, Semjen, and Bonnet 1984, 467). In 1984 leading Western specialists called Bernshteyn "a precursor of cognitive neurobiology" (ibid., 471).

\section{Reconciling Reflex Theory with Cybernetics}

With the rise of cybernetics and cultural legitimation of man-machine metaphors, the Pavlovians faced a difficult choice. Either they had to continue denying the philosophical validity of cybernetics, or they had to find some form of reconciliation between Pavlov's doctrine and cybernetics. In either case cybernetic metaphors had to be reinterpreted once again: some were taken as implicit philosophical statements, and some were construed broadly to fit the Pavlovian conceptual framework. A decisive clash between the opponents and the proponents of "physiological cybernetics" occurred at the 1962 Conference on Philosophical Questions of the Physiology of Higher Nervous Activity and Psychology.

The more dogmatic Pavlovians chose the first strategy. This time they accused cyberneticians largely of an "idealistic," rather than "mechanistic," deviation from dialectical materialism. Cybernetic models had no basis in actual neurophysiological processes, they argued, and these models were therefore "detached" from material reality. Alluding to Lenin's "classical" critique of the "idealistic" philosophical interpretations of the crisis in physics in which "matter disappeared and only equations remained," one of the conference participants claimed that in Bernshteyn's theory "physiological processes in the brain are supplanted with the technology of mathematical thinking," "reflex mechanisms of functioning of the nervous system totally disappear" and "only mathematical transformations remain" (Fedoseyev 1963, 558). While cyberneticians claimed that the feedback-based model of purposeful behavior had bridged the gap between mechanical causality and teleology, Soviet critics initially accused them of reducing everything to mechanical causality ("mechanicism"), and now the critical emphasis shifted to teleology (which the critics closely associated with vitalism and idealism). Criticizing Bernshteyn's notion of the "inborn program of development," one speaker asked rhetorically: "Who compiled this program and put it into living matter, like in a cybernetic machine? There is a strong smell of Aristotle's entelechy here" (ibid., 584). ${ }^{4}$

\footnotetext{
${ }^{4}$ Aristotle called the form or "vital function" (the "soul," or inner activity) of an organism, as opposed to the passive matter of which it was composed, entelechy. This notion was revived at the turn of the twentieth century by the German biologist and philosopher Hans Driesch in his vitalistic theory. Western cyberneticsminded biologists also had reservations about the notion of teleology and preferred to replace it with the less offensive teleonomy, which described adaptation as the activation of a preexisting finite storage of genetic information (Kay 2000, 196).
} 
The more politically savvy among Pavlov's followers were aware that times had changed. When they realized that they could not defeat cybernetics, they decided to join it. Initially they claimed that cybernetics contradicted Pavlov's teaching and was therefore a pseudo-science, but now they completely embraced cybernetics and argued, with equal zeal, that reflex theory fully agreed with cybernetics, and that Pavlov himself was all but the founding father of cybernetics. Wiener had earlier attempted to connect feedback control mechanisms with the widely recognized Pavlovian theory of conditional reflexes to add credibility to cybernetics; now clever Pavlovians used the same discursive strategy, only this time to salvage Pavlov's doctrine by associating it with the widely recognized cybernetic ideas. Yuriy Frolov, one of Pavlov's orthodox disciples, unearthed a forgotten 1936 article by the mathematician N. A. Romanov, who had proposed a probabilistic model of Pavlovian reflexes. "Of course, this does not mean that cybernetics was 'discovered' in Pavlov's laboratory," admitted Frolov, "but this testifies to the fact that the mathematician Romanov ... was the first to point out the closest connection between the teaching of Pavlov and the theory of probabilities as the core of modern cybernetics" (Frolov 1961, 314).

Pëtr Anokhin was among the first of Pavlov's former disciples to realize the prospects opened to physiological research by cybernetics. In 1955, he was appointed chairman of the Department of Normal Physiology at the First Medical Institute in Moscow; soon he equipped his laboratory with the newest electric stimulators, amplifiers, and encephalographs. At first his research agenda remained largely Pavlovian (the study of conditional reflexes related to the activity of the salivary gland), only now, instead of collecting saliva, he registered electric potentials of a dog's brain (Simonov 1990, 136-37). With the rise of cybernetics in the late 1950s, however, Anokhin decided to revive and legitimize his early ideas about functional systems, presenting his approach as a precursor to cybernetics:

We proposed the notions of functional system and return afferentation eleven years before the advent of cybernetics. . . . For many years, however, the idea of functional system remained a guiding one for our laboratory only. ... The development of cybernetics with its fundamental principle of feedback regulation has changed the situation dramatically. The fundamental principle of automatic regulation with feedback as the basis of cybernetics has proved strikingly identical with our ideas about a "closed functional system.” (Anokhin [1963] 1978, 200-205)

This "striking identity" was hardly surprising, considering that Wiener and Rosenblueth formulated their concept of physiological feedback based on a long tradition of closed-loop physiological models, from Claude Bernard to Walter Cannon, which must have been known to Anokhin as well. 
Anokhin was always careful to portray his own views as being within the Pavlovian framework, and his approach took form as a hybrid of Pavlov's reflex theory and "physiological cybernetics." While Bernshteyn actively used cybernetic language to undermine the Pavlovian conceptual framework with cybernetic metaphors, Anokhin avoided this language and even warned against "the tendency to substitute physiological terms and concepts with terms borrowed from the arsenal of cybernetics," such as information, coding, and programming (Anokhin [1957] 1978, 213). Instead, Anokhin attempted to create his own physiological vocabulary. He replaced his earlier term sanctioning afferentation with more general return afferentation (obratnaya afferentatsiya), which, in his view, was somewhat similar to but richer in content than feedback (obratnaya svyaz'). He also introduced the terms afferent synthesis (the integration of all signals about the results of previous actions and the formation of the next action's goal) and acceptor of action (the "apparatus that accepts return afferentation and compares it to the goal of a given action"). In Anokhin's view, these three physiological mechanisms - afferent synthesis, return afferentation, and acceptor of action - played a key role "not only in the conditional reflex, but also in any complete behavioral act, especially in purposeful behavior" (Anokhin [1963] 1978, 193-95). These three mechanisms also constituted a new, improved concept of a functional system. If the 1930 s version described a physiological process directed at a specific goal, namely, the compensation of lost functions, the new concept of functional system was proposed as a mechanism of any physiological activity.

The 1962 conference was a "major sign of the shift to cybernetic modeling" of nervous activity (Joravsky 1989, 533). This shift was moderated, however, by the successful attempts by Anokhin and his supporters to reconcile cybernetics with Pavlovian physiology. Anokhin maintained that his theory of functional systems was broad enough to encompass both Pavlov's reflex theory and cybernetics. He argued that the conditional reflex was just a "particular case" in the workings of a functional system, while the latter represented a "universal principle." Trying to incorporate cybernetics into his overarching theory, Anokhin formulated what he called a "cardinal law of life, which determines all forms of human adaptation, including complex automatic regulating machines": "any functional system, mechanical or living, created or developed by itself in order to produce a useful effect, must necessarily have a cyclical character and cannot exist without receiving return signals about the efficacy of the produced effect" (Anokhin [1957] 1978, 222-23). At this level of generality, cybernetic ideas seemed entirely compatible both with Pavlov's teachings and with dialectical materialism.

Anokhin strove to integrate "physiological cybernetics" into mainstream physiology both intellectually and institutionally. He worked closely with the Academy Council on Cybernetics, and after Bernshteyn's and Tsetlin's deaths in the latter half of the 1960s Anokhin's interpretation of "physiological cybernetics" began to dominate. In 1966, with the support of the Council's influential chairman, Aksel' Berg, Anokhin was elected a full member of the Soviet Academy of Sciences and rose 
to leading positions in Soviet physiology. His mild version of "physiological cybernetics" no longer posed a challenge to Pavlovian orthodoxy, as did Bernshteyn's radical approach. Anokhin's school excluded extreme interpretations of cybernetic ideas and metaphors to create a middle-of-the-road combination of Pavlov's reflex theory and feedback-based cybernetic mechanisms. This sterilized version proved most acceptable politically, and it became one of the most influential physiological doctrines in the Soviet Union.

The relationship between cybernetics and the Pavlovian theory was not fixed; on the contrary, it evolved as these theories themselves were being reinterpreted and their central metaphors reconsidered. This dynamic reflected profound changes in the sociopolitical context of Soviet physiological research. When cybernetics was publicly condemned as a "pseudo-science," the Pavlovians argued that Pavlov's teachings had nothing to do with ideologically suspect mathematical models and man-machine metaphors. When cybernetics became a legitimate and respectable field of study, the Pavlovians, with equal zeal, scrambled to read cybernetics into the Pavlovian doctrine. Soviet cyberneticians, on the other hand, at first argued full compatibility of cybernetics with reflex theory, trying to gain legitimacy from an association with the dominant physiological theory. Later, when cybernetics was standing on its own feet, they made a complete turnaround and employed cybernetic models to challenge the Pavlovian theory. Man-machine metaphors traveled from one discipline to another and back again, and changed valences and allegiances, depending on the current political and cultural situation.

The case of "physiological cybernetics" suggests that scientific language and particularly its metaphors are instrumental in shaping scientific debates and research agenda, and this holds true more generally. The history of Soviet cybernetics demonstrates the political and cultural significance of cybernetic man-machine metaphors for a wide range of scientific disciplines - from biology to linguistics to economics. The language of cybernetics - cyberspeak - played an essential role in the intellectual and institutional transformations of these disciplines in the 1950s and 1960s. Many previously suppressed research trends were legitimized by means of translation into cyberspeak. Political and institutional changes in Soviet science during Khrushchev's “Thaw" were closely tied with the struggle between the new metaphorical language of cybernetics and the old Stalinist language of ideological clichés (Gerovitch 2002).

When man-machine metaphors travel among different disciplines and historical contexts, they return in a new guise, which sometimes renders them more powerful. In the 1930s, when Anokhin and Bernshteyn first put forward their ideas of "reflex circle" and "return afferentation," which did not fit the Pavlovian conceptual framework, the Soviet physiology community did not accept their approaches. Only when the idea of a closed-loop physiological process was combined with the notion of feedback from control engineering, generalized by cyberneticians, and legitimized in the Soviet Union as a distinctively cybernetic rather than physiological concept, did Soviet physiologists begin to reconsider their dominant metaphor. 


\section{Man-Machine Metaphors: Travels Between Physiology and Technology}

Bernshteyn realized that his own work, as well as the Pavlovian doctrine, belonged to the age-old tradition of borrowing physiological models from contemporary technology. He even coined the term "semeromorphism" ("shaping in today's image") to denote this tradition. ${ }^{5}$ Bernshteyn objected to Pavlov's reflex theory not because it was based on a man-machine metaphor, but because it was based on a simplistic man-machine metaphor - a flaw which Bernshteyn aspired to correct by suggesting a more sophisticated machine analogy, the one between man and computer.

Every period in human history comes with its own machines and its own manmachine metaphors. John Daugman has listed some famous examples of such metaphors in the history of neurophysiology:

Theorizing about brain and mind has been especially susceptible to sporadic reformulation in terms of the technological experience of the days. For example, the water technology of antiquity (fountains, pumps, water clocks) underlies the Greek pneumatic concept of the soul (pneuma) and the Roman physician Galen's theory of the four humours; the clockwork mechanisms proliferating during the Enlightenment are ticking with seminal influence inside La Mettrie's L'Homme Machine (1748); Victorian pressurized steam engines and hydraulic machines are churning underneath Freud's hydraulic construction of the unconscious and its libidinal economy; the arrival of the telegraph network provided Helmholtz his basic neural metaphor, as did reverberating relay circuits and solenoids for Hebb's theory of memory and so on. (Daugman 1990, 10)

The entire history of physiology is filled with technological metaphors: Plato compared the vertebrae to door-hinges and the blood-vessels to irrigation canals; Aristotle likened the bones and tendons of the fore-arm to the arms of a catapult drawn back by tightening cables; Harvey drew an analogy between the valves of veins and mechanical valves ("lock-gates"); Descartes was inspired by water-driven automata in the grottoes of the Royal Gardens at Saint-Germain-en-Laye; Liebig's view of digestion as combustion was based on the metaphor of the body as a furnace and the food as the fuel; and Helmholtz interpreted the body as a heat engine. The metaphor of the human motor - the body as a machine consuming energy and producing work - became a central metaphor of modernity (Canguilhem 1988; Coleman 1971, 118-59; Krementsov and Todes 1991; Toulmin and Goodfield 1962, 307-37; Rabinbach 1990; Vartanian 1973).

Machine metaphors followed one another in long chains, informing the development of whole branches of physiology. George Canguilhem, for example,

\footnotetext{
${ }^{5}$ Bernshteyn ([1958] 1997) derived the term "semeromorphism" from the Greek $\sigma \eta \mu \varepsilon \rho o v$ (today) and $\mu о \rho \varphi \eta$ (a form, a shape).
} 
traced "the successive identification of the nerve with a non-isolated, passive electric conductor (submarine cable), then with an electro-chemical assembly . . . simulating the propagation of an impulse and the establishment of an insensitive period, and finally with a model of an electric circuit, combining a battery with a grid-leak condenser, capable of exhibiting the equivalent of eighteen properties of nerves and synapses" (Canguilhem 1963, 518). He was convinced, however, that such models had limited utility and called on his readers not to forget that "scientists like Sherrington and Pavlov did not work by constructing models" (ibid., 520). These names, however, can hardly serve to illustrate this point; quite the opposite, they aptly reflect the pervasiveness of man-machine metaphors. If Pavlov himself did not construct any actual mechanical models to support his theory, others quite successfully did it for him. Besides Babat's electronic "dog" mentioned above, one could cite the work of Clark Hull and his co-workers, who built a series of mechanical and electro-mechanical "psychic machines" that imitated Pavlovian reflexes. When these devices were subjected to certain combinations of excitatory and inhibitory signals, they exhibited well-known conditioning phenomena, such as generalization, higher-order conditioning, and persistence of responding until the attainment of a goal object (Smith 1990, 250-51). As for Sherrington, in 1906 he famously described the brain as an "enchanted loom," in which "millions of flashing shuttles weave a dissolving pattern" - an expression that Daugman has called "perhaps one of the more beautiful twentieth-century incarnations of the mechanical metaphor" (Daugman 1990, 13).

Any metaphor is double-sided: by tying together two different conceptual systems, it urges us to look at both concepts from a new angle. As Kenneth Burke puts it, the metaphor asserts not only the "thisness of a that," but also the "thatness of a this" (quoted in Sapir 1977, 11). With man-machine analogies, the prospect of such inversion is particularly striking: the reverse side of a machine metaphor applied to a human being is an anthropomorphic metaphor applied to a machine. Man-machine analogies not only informed the development of anthropomorphic mechanisms, or automata, which explicitly imitated human functions (Cohen 1966), but also shaped the cultural image of new technologies, for example, the telephone.

Ironically, at the same time that Pavlov was comparing the central nervous system to a telephone switchboard, communication engineers working on actual telephone networks were comparing them to the nervous system. In 1907, John J. Carty, chief engineer of the Bell system, called the telephone network "society's nervous system." In 1925, another Bell engineer compared a modern telephone cable with the human spinal cord:

The spinal cord of an individual is the conduit of the main nerves which go out from the brain and over which intelligence may be flashed to any part of the body . . . In similar manner the long-distance cables of the modern telephone plant connect physically the 
widespread members and communities of the social and economic structure of the nation. (Quoted in Mindell 1996, 213)

Bell Laboratories Record called the newly introduced automatic switchboard a "mechanical brain." The terms "singing" and "howling," which described various disturbances in telephone equipment, added to the distinguished line of manmachine and dog-machine analogies that circulated between physiology and communication engineering.

Man-machine metaphors travel constantly back and forth between the spheres of physiology and technology. Technical devices imitate human body functions, then organisms are described in technological terms, following which new machines appear based on the "mechanisms" of the functioning of these technologically perceived bodies, and so on. As David Leary has observed, the Cartesian analogy between the human body and water-driven human statues provides "another example of someone taking a humanly constructed analog - this time an animated statue made in the image and likeness of human beings - and then using this analog as a means of reflecting on human nature, that is, on the very aspect of nature that had been the model for the analog in the first place" (Leary 1990, 16). If we allow ourselves to resort to a cybernetic metaphor, we might describe this process as feedback loop of man-machine metaphors: the more anthropomorphic the machines look, the more machine-like appear the human beings.

Geoffrey Bowker has argued that the metaphorical language of cybernetics served an important social function by supporting "legitimacy exchange" among scientists. "An isolated scientific worker making an outlandish claim could gain rhetorical legitimacy by pointing to support from another field - which in turn referenced the first worker's field to support its claims. The language of cybernetics provided a site where this exchange could occur." For example, A. M. Uttley, the author of the "conditional probability machine," "used mathematics to support his physiology and physiology to support his mathematics, using cybernetic terminology to spiral between the formal properties of classification machines and the nature of the brain" (Bowker 1993, 116). ${ }^{6}$

Cyberneticians did not merely describe computers metaphorically as brains; the brain itself was conceptualized in logical and engineering terms, and these concepts then returned to computing, serving as a basis for the impressive "discoveries" of man-machine analogies. On the first pages of his Cybernetics, Wiener suggested the computer as a model for the nervous system: "It became clear to us [Wiener and Pitts] that the ultra-rapid computing machine, depending as it does on consecutive switching devices, must represent almost an ideal model of the problems arising in the nervous system" (Wiener [1948] 1961, 14). A few pages down, he turned this analogy around and described the computer itself in neurophysiological terms: "The modern

\footnotetext{
${ }^{6}$ Susan Leigh Star (1989) has called this mechanism of claim exchange a "triangulation effect."
} 
ultra-rapid computing machine was in principle an ideal central nervous system to an apparatus for automatic control" (ibid., 26). In another instance, physiological homeostasis was conceptualized as a feedback-controlled servomechanism, while servomechanisms themselves were described in anthropomorphic terms. As Lily Kay observed, "signifying homeostasis as negative feedback and then resignifying such servomechanisms as organismic homeostasis amounted to a circularity" (Kay 2000, 83).

Man-machine metaphors travel by a spiral rather than a circle: at each stage new, more complex machines provide metaphors for more sophisticated physiological concepts, and vice versa. Old machine metaphors are usually perceived as "mechanistic" and reductionist; new machine metaphors, on the contrary, often seem liberating by overcoming some limitations of the old models. In the eighteenth century, for example, La Mettrie ridiculed the Cartesian "dead mechanism"; instead, he conceptualized the human body as a "machine that winds its own springs" and compared the human brain to a harpsichord (Vartanian 1973, 139-40). In the nineteenth-century, French physiology was witnessing a vigorous debate between Claude Marey and Claude Bernard, which Marey viewed as an episode in "the eternal struggle in science between the mysticism of the vitalists and the rationalism of the mechanists; between the heirs of Plato and the heirs of Aristotle" (Rabinbach 1990, 91-92). Bernard considered Marey's views mechanistic, for the latter claimed that the "animal organism is no different from our machines, except for their greater efficiency" (quoted in ibid., 90). Yet Bernard himself borrowed such terms as equilibrium, compensation, balance, and regulation from the vocabulary of contemporary engineers, introducing the notions of "calorific regulation" and "nervous autoregulator" into physiology. Noting the flood of publications on "the regulation of ..." and "the regulatory mechanism of ..." that followed Bernard's work, Canguilhem observed: "After Bernard the word regulation entered the common vocabulary of physiology. When a word appears in the title of a book or paper, it has been recognized as more than a mere metaphor by the competent scientific community .... Regulation, having begun as a purely mechanical concept, had become a biological concept as well. Later, through the mediation of homeostasis, it would become a concept of cybernetics" (Canguilhem 1988, 100-101).

As we have seen in the history of Soviet physiology, while the debates were often conducted in the form of critique of mechanistic reductionism, all sides in fact adhered to some basic man-machine metaphors of their own. Dogmatic Pavlovians labeled cybernetic ideas "mechanistic," while they treasured the central Pavlovian switchboard metaphor. "Physiological cyberneticians" like Bernshteyn, on the other hand, associated Pavlov's views with "classical mechanicism" and did not see their own metaphors for human physiology - the servomechanism and the computer - as reductionist. As machines became more sophisticated, so did man-machine metaphors. The notion of "mechanistic reductionism" changed correspondingly: it referred to degrading analogies with the primitive machines of the past, while 
parallels with the complex, fascinating machines of today often looked uplifting and inspiring.

Traveling freely between technology and physiology, man-machine metaphors seem to have destabilized the meanings of "man" and "machine" long before the advent of the cyborg. New technologies steadily expanded the realm of machine functions and disseminated totally new meanings of "mechanism." "In the last 350 years, the terms 'machine' and 'mechanism' have shifted their meanings slowly but drastically; and the aims and strategy for a 'mechanistic' science of physiology have shifted with them," argued Stephen Toulmin. "As a result, the line of battle between mechanists and vitalists, reductionists and holists, has never been - and can never be - drawn in definitive terms; for all the key terms involved (force, cause, nerves, even molecule) have been subject to the same conceptual evolution" (Toulmin 1993, 145). The introduction of feedback-controlled cybernetic devices capable of "selfregulation" drastically redefined the scientific and cultural meaning of the "machine." "If Descartes, Newton or Leibnitz had been shown a late 20th century computer," wrote Toulmin, "they could only have reacted by declaring, 'That's not [i.e. that's not what we call] a "machine" at all!" (ibid., 145-46).

The attempts to define organic as something essentially opposite to mechanical should also be historically situated. While in the sixteenth century these terms were synonymous (organic was derived from organ, or instrument), in the nineteenth century the Romantic movement made a fundamental conflict between the "organic" and the "mechanical" one of its central tenets (Williams 1985, 227-229). Carolyn Merchant, who famously contrasted "the mechanical order," responsible for "the death of nature," with the holistic "organic world," in the end admitted that "the organic and mechanical philosophies of nature cannot ... be viewed as strict dichotomies" (Merchant 1980, 103). What on the surface often appeared as a struggle between "organic" and "mechanistic" views of the world may in the end prove to be a battle between old and new machine metaphors.

The fundamental reversibility of man-machine metaphors has deeply affected the development of both technology and physiology. Perhaps one could read the history of technology as a succession of anthropomorphic metaphors, and the history of physiology as a metaphorical reflection of the development of machines.

\section{Acknowledgments}

The first version of this article was presented at the Joint Atlantic Seminar in the History of Biology in April 1994. It was inspired by my discussions with the late Lily E. Kay, a stimulating teacher, an uncompromising critic, and a wonderful intellectual companion, who gave me much-needed advice and encouragement to work on this topic. The second, revised and expanded, version appeared as part of my doctoral dissertation, "Speaking Cybernetically: The Soviet Remaking of an American Science" (Program in Science, Technology and Society, MIT, 1999). While working 
on the dissertation, I greatly benefited from the advice of Loren R. Graham, Jed Z. Buchwald, Thomas P. Hughes, and Elizabeth Wood. The present version is the result of substantial revisions after comments from Alexei Kojevnikov and anonymous referees of Science in Context. I wish to thank all of them for constructive criticism and helpful suggestions.

\section{References}

Adams, Mark B. 1977-1978. "Biology After Stalin.” Survey 23:53-80.

Anonymous. 1954. "Kibernetika." In Kratkiy filosofskiy slovar', edited by Mark Rozental' and Pavel Yudin, 236-37. Moscow: Gospolitizdat.

Anokhin, Pëtr K. 1978. Filosofskiye aspekty teorii funktsional'noy sistemy: Izbrannyye trudy, edited by Fëdor V. Konstantinov et al. Moscow: Nauka.

Anokhin, Pëtr K. n.d. "Zamechaniya po povodu retsenzii E. A. Shkabara and L. N. Dashevskogo na stat'yu o 'kibernetike'." Russian State Archive of Literature and Art (Rossiyskiy Gosudarstvennyi arkhiv literatury $i$ iskusstva [RGALI]), f. 634, op. 3, d. 206, 11. 139-140.

Arbib, Michael A., and Mary Hesse. 1986. The Construction of Reality. Cambridge: Cambridge University Press.

Bailes, Kendall. 1977. "Alexei Gastev and the Soviet Controversy over Taylorism, 1918-1924.” Soviet Studies 29:373-394.

Bernshteyn, Nikolay A. 1962. "Puti razvitiya fiziologii i svyazannyye s nimi zadachi kibernetiki." In Biologicheskiye aspekty kibernetiki, edited by Aleksandr M. Kuzin, 52-65. Moscow: AN SSSR.

Bernshteyn, Nikolay A. 1966. Ocherki po fiziologii dvizheniy i fiziologii aktivnosti. Moscow: Meditsina.

Bernstein, Nicholas (Bernshteyn, Nikolay). 1967. The Co-ordination and Regulation of Movements, translated from Russian and German. Oxford: Pergamon Press.

Bernshtein, Nikolai A. (Bernshteyn, Nikolay). 1969. "Methods for Developing Physiology as Related to the Problems of Cybernetics." In A Handbook of Contemporary Soviet Psychology, edited by Michael Cole and Irving Maltzman, translated by Rosa Glickman et al., 441-51. New York: Basic Books.

Bernshteyn, Nikolay A. 1997. Biomekhanika i fiziologiya dvizheniy, edited by Vladimir P. Zinchenko. Moscow and Voronezh: MODEK.

Bongard, Mikhail. 1970. Pattern Recognition, translated from Russian. New York: Spartan Books.

Bono, James J. 1990. "Science, Discourse, and Literature: The Role/Rule of Metaphor in Science." In Literature and Science: Theory and Practice, edited by Stuart Peterfreund, 59-89. Boston: Northeastern University Press.

Bowker, Geof. 1993. "How to be Universal: Some Cybernetic Strategies, 1943-70.” Social Studies of Science 23:107-127.

Boyd, Richard. 1993. "Metaphor and Theory Change: What Is a 'Metaphor' a Metaphor For?" In Metaphor and Thought, edited by Andrew Ortony, 356-408. Cambridge, UK: Cambridge University Press.

Bykhovskiy, Bernard E. 1952. “Kibernetika - amerikanskaya lzhenauka.” Priroda 7:125-127.

Bykhovskiy, Bernard E. 1953. "Nauka sovremennykh rabovladel'tsev.” Nauka i zhizn' 6:42-44.

Canguilhem, Georges. 1963. "The Role of Analogies and Models in Biological Discovery.” In Scientific Change: Historical Studies in the Intellectual, Social and Technical Conditions for Scientific Discovery and Technical Invention, from Antiquity to the Present, edited by Alistair C. Crombie, 507-20. London: Heinemann.

Canguilhem, Georges. 1988. "The Development of the Concept of Biological Regulation in the Eighteenth and Nineteenth Centuries." In Ideology and Rationality in the History of the Life Sciences, translated by Arthur Goldhammer, 81-102. Cambridge, Mass.: MIT Press. 
Chkhaidze, LevanV. 1965. Koordinatsiya proizvol'nykh dvizheniy cheloveka v usloviyakh kosmicheskogo polëta. Moscow: Nauka.

Cohen, John. 1966. Human Robots in Myth and Science. London: Allen \& Unwin.

Coleman, William. 1971. Biology in the Nineteenth Century. Cambridge, UK: Cambridge University Press.

Daugman, John G. 1990. "Brain Metaphor and Brain Theory.” In Computational Neuroscience, edited by Eric L. Schwartz, 9-18. Cambridge, Mass.: MIT Press.

Demidov, Vyacheslav E. 1989. "U istokov fiziologii aktivnosti. Nikolay Aleksandrovich Bernshteyn i razvitiye otechestvennykh biokiberneticheskikh issledovaniy." In Kibernetika: proshloye dlya budushchego. Etyudy po istorii otechestvennoy kibernetiki, edited by Boris V. Biryukov, 108-69. Moscow: Nauka.

Edwards, Paul. 1996. The Closed World: Computers and the Politics of Discourse in Cold War America. Cambridge, Mass.: MIT Press.

Fedoseyev, Pëtr N., ed. 1959. Filosofskiye problemy sovremennogo yestestvoznaniya: Trudy Vsesoyuznogo soveshchaniya po filosofskim voprosam yestestvoznaniya. Moscow: AN SSSR.

Fedoseyev, Pëtr N., ed. 1963. Filosofskiye voprosy fiziologii vysshey nervnoy deyatel'nosti i psikhologii. Moscow: AN SSSR.

Foucault, Michel. 1980. Power/Knowledge: Selected Interviews and Other Writings, 1972-1977, edited by Colin Gordon, translated by Colin Gordon et al. New York: Pantheon.

Frolov, Yuriy P. 1961. "Dialektika zhivoy prirody i sovremennaya kibernetika." In Filosofskiye voprosy kibernetiki, edited by Viktor A. Il'in, et al., 306-24. Moscow: Izdatel'stvo sotsial'no-ekonomicheskoy literatury.

Galison, Peter L. 1994. "The Ontology of the Enemy: Norbert Wiener and the Cybernetic Vision." Critical Inquiry 21:228-266.

Gal'perin, I. I. 1957. "O reflektornoy prirode upravlyayushchikh mashin (Otvet inzhenera fiziologam)." Voprosy filosofii 4:158-168.

Gerovitch, Slava. 2000. "Striving for 'Optimal Control': Soviet Cybernetics as a 'Science of Government."' In Cultures of Control, edited by Miriam R. Levin, 247-64. Amsterdam: Harwood Academic Publishers.

Gerovitch, Slava. 2001a. “Mathematical Machines' of the Cold War: Soviet Computing, American Cybernetics and Ideological Disputes in the Early 1950s." Social Studies of Science 31:253-187.

Gerovitch, Slava. 2001b. "Russian Scandals': Soviet Readings of American Cybernetics in the Early Years of the Cold War." Russian Review 60:545-568.

Gerovitch, Slava. 2002. From Newspeak to Cyberspeak: A History of Soviet Cybernetics. Cambridge, Mass.: MIT Press.

Gillespie, R. David. 1974. "The Politics of Cybernetics in the Soviet Union." In Scientists and Public Affairs, edited by Albert H. Teich, 239-298. Cambridge, Mass.: MIT Press.

Gladkov, Teodor K. 1955. "Kibernetika - psevdonauka o mashinakh, zhivotnykh, cheloveke i obshchestve." Vestnik Moskovskogo universiteta 1:57-67.

Golikov, Yu.P., and K.A. Lange, comps. 1999. I. P. Pavlov: pro et contra. St. Petersburg: RKhGI.

Graham, Loren R. 1987. Science, Philosophy, and Human Behavior in the Soviet Union. New York: Columbia University Press.

Grigoryan, Noravard A. 1999. Ivan Petrovich Pavlov. Moscow: Nauka.

Haraway, Donna. 1991. "A Cyborg Manifesto: Science, Technology, and Socialist-Feminism in the Late Twentieth Century." In Simians, Cyborgs, and Women: The Reinvention of Nature, 149-181. New York: Routledge.

Heims, Steve J. 1980. John von Neumann and Norbert Wiener: From Mathematics to the Technologies of Life and Death. Cambridge, Mass.: MIT Press.

Heims, Steve J. 1993. Constructing a Social Science for Postwar America: The Cybernetics Group, 1946-1953. Cambridge, Mass.: MIT Press. 
Hoffman, Robert R., Edward L. Cochran, and James M. Nead. 1990. "Cognitive Metaphors in Experimental Psychology." In Metaphors in the History of Psychology, edited by David E. Leary, 173-229. Cambridge, UK: Cambridge University Press.

Holloway, David. 1974. "Innovation in Science - the Case of Cybernetics in the Soviet Union." Science Studies 4:299-337.

Hughes, Agatha C., and Thomas P. Hughes, eds. 2000. Systems, Experts, and Computers: The Systems Approach in Management and Engineering, World War II and After. Cambridge, Mass.: MIT Press.

Ivanov, VyacheslavVs. 1998. "Iz istorii kibernetiki v SSSR. Ocherk zhizni i deyatel'nosti M. L. Tsetlina." In Ocherki istorii informatiki $v$ Rossii, edited by Dmitriy A. Pospelov and Yakov I. Fet, 556-80. Novosibirsk: OIGGM SO RAN.

Johansson, Kurt. 1983. Aleksej Gastev: Proletarian Bard of the Machine Age. Stockholm, Sweden: Almqvist $\&$ Wiksell International.

Josephson, Paul R. 1997. New Atlantis Revisited: Akademgorodok, the Siberian City of Science. Princeton, New Jersey: Princeton University Press.

Joravsky, David. 1989. Russian Psychology: A Critical History. Oxford, UK: Basil Blackwell.

Kay, Lily E. 2000. Who Wrote the Book of Life? A History of the Genetic Code. Stanford, Calif.: Stanford University Press.

Keldysh, Mstislav V., Aleksey A. Lyapunov, and Mikhail R. Shura-Bura. 1957. "Matematicheskiye voprosy teorii schëtnykh mashin." In Sessiya Akademii nauk SSSR po nauchnym problemam avtomatizatsii proizvodstva, 15-20 oktyabrya 1956 g.: Plenarnyye zasedaniya, edited by Vadim A. Trapeznikov, 100-30. Moscow: AN SSSR.

Kirillin, Vladimir, and Konstantin Frolov. 1958. "V TsK KPSS." The Russian State Archive of Contemporary History (Rossiyskiy gosudarstvennyi arkhiv noveyshey istorii [RGANI]), f. 5, op. 35, d. 76, 11. 161-162.

Kolmogorov, Andrey N. 1963. “Avtomaty i zhizn'.” In Vozmozhnoye i nevozmozhnoye v kibernetike, edited by Aksel' I. Berg, and Ernest Kol'man, 10-29. Moscow: AN SSSR.

Kozulin, Alex. 1984. Psychology in Utopia: Toward a Social History of Soviet Psychology. Cambridge, Mass.: MIT Press.

Krementsov, Nikolai. 1997. Stalinist Science. Princeton, N.J.: Princeton University Press.

Krementsov, Nikolai L., and Daniel P. Todes 1991. "On Metaphors, Animals, and Us.” Journal of Social Issues 47:67-81.

Leary, David E. 1990. "Psyche's Muse: The Role of Metaphor in the History of Psychology." In Metaphors in the History of Psychology, edited by David E. Leary, 1-78. Cambridge, UK: Cambridge University Press.

Lentin, André. 1953. "La cybernétique: problèmes réels et mystification.” La Pensée 47: 47-61.

Leont'ev, Aleksey N., et al. 1954. "Otchet o deyatel'nosti delegatsii sovetskikh uchënykh-psikhologov na XIV Mezhdunarodnom psikhologicheskom kongresse v Monreale." Russian State Archive of Contemporary History (Rossiyskiy gosudarstvennyi arkhiv noveyshey istorii [RGANI]), f. 5, op. 16, d. 468, 11. 111-147.

Lyapunov, Aleksey A. [1958] 1980. "O nekotorykh obshchikh voprosakh kibernetiki." In Problemy teoreticheskoy i prikladnoy kibernetiki, edited by Sergey L. Sobolev, 54-71. Moscow: Nauka.

Lyapunov, Aleksey A., and Sergey V. Yablonskiy. [1963] 1980. "Teoreticheskiye problemy kibernetiki." In Problemy teoreticheskoy i prikladnoy kibernetiki, edited by Sergey L. Sobolev, 71-88. Moscow: Nauka.

Materialist [pseudonym]. [1953] 1974. "Whom Does Cybernetics Serve?” translated by Alexander D. Paul. Soviet Cybernetics Review 4:32-45.

McCulloch, Warren S., and Walter Pitts. 1943. "A Logical Calculus of the Ideas Immanent in Nervous Activity." Bulletin of Mathematical Biophysics 5:115-133.

Medvedev, Nikolay V. 1954. Marksistsko-leninskaya teoriya otrazheniya i ucheniye I. P. Pavlova o vysshey nervnoy deyatel'nosti. Moscow: Gospolitizdat.

Medvedev, Zhores A. 1978. Soviet Science. New York: W. W. Norton. 
Merchant, Carolyn. 1980. The Death of Nature: Women, Ecology, and the Scientific Revolution. San Francisco: Harper \& Row.

Mindell, David A. 1996. “'Datum for Its Own Annihilation:' Feedback, Control, and Computing, 1916-1945.” Ph.D. diss., Massachusetts Institute of Technology.

Mirowski, Philip. 1991. "When Games Grow Deadly Serious: The Military Influence on the Evolution of Game Theory." In Economics and National Security, edited by Craufurd Goodwin, 227-55. Durham and London: Duke University Press.

Mirowski, Philip. 1992. "What Were von Neumann and Morgenstern Trying to Accomplish?” In Toward a History of Game Theory, edited by E. Roy Weintraub, 111-47. Durham and London: Duke University Press.

Neumann, John von. 1958. The Computer and the Brain. New Haven: Yale University Press.

Parin, Vasiliy V., et al., eds. 1969. Problemy kibernetiki: Nekotoryye itogi i problemy filosofsko-metodologicheskikh issledovaniy. Moscow: Znaniye.

Pavlov, Ivan P. [1909] 1996. "Yestestvoznaniye i mozg." In Mozg i psikhika: Izbrannyye psikhologicheskiye trudy, edited by Mikhail G. Yaroshevskiy, 67-78. Moscow and Voronezh: MODEK.

Pavlov, Ivan P. [1916] 1928. “The Reflex of Purpose." In Lectures on Conditioned Reflexes, translated by W. Horsley Gantt, 275-81. New York: International Publishers.

Pavlov, Ivan P. [1927] 1949. Lektsii o rabote bol'shikh polushariy golovnogo mozga, edited by K. M. Bykov. Moscow: Izdatel'stvo Akademii nauk SSSR.

Pavlov, Ivan P. [1932] 1996. "Otvet fiziologa psikhologam." In Mozg i psikhika: Izbrannyye psikhologicheskiye trudy, edited by Mikhail G. Yaroshevskiy, 151-83. Moscow and Voronezh: MODEK.

Pavlov, Ivan P. [1936] 1996. "Uslovnyi refleks." In Mozg i psikhika: Izbrannyye psikhologicheskiye trudy, edited by Mikhail G. Yaroshevskiy, 242-63. Moscow and Voronezh: MODEK.

Pickering, Andy. 1995. "Cyborg History and the WWII Regime." Perspectives on Science 3:1-48.

Pribram, Karl H. 1990. "From Metaphors to Models: The Use of Analogy in Neuropsychology." In Metaphors in the History of Psychology, edited by David E. Leary, 79-103. Cambridge, UK: Cambridge University Press.

Rabinbach, Anson. 1990. The Human Motor: Energy, Fatigue, and the Origins of Modernity. Berkeley, Calif.: University of California Press.

Requin, J., A. Semjen, and M. Bonnet. 1984. "Bernstein's Purposeful Brain.” In Human Motor Actions: Bernstein Reassessed, edited by H.T.A. Whiting, 467-99. Amsterdam: North Holland.

Sapir, J. David. 1977. "The Anatomy of Metaphor." In The Social Use of Metaphor: Essays on the Anthropology of Rhetoric, edited by J. David Sapir and J. Christopher Crocker, 3-32. Philadelphia: University of Pennsylvania Press.

Shannon, Claude E., and Warren Weaver. 1949. The Mathematical Theory of Communication. Urbana, Ill.: University of Illinois Press.

Shapin, Steven, and Simon Schaffer. 1985. Leviathan and the Air-Pump: Hobbes, Boyle, and the Experimental Life. Princeton, N.J.: Princeton University Press.

Simonov, PavelV., ed. 1990. Pëtr Kuz'mich Anokhin: Vospominaniya sovremennikov, publitsistika. Moscow: Nauka.

Sirotkina, Irina. 1995. "N. A. Bernshtein: The Years Before and After the 'Pavlov Session'." Russian Studies in History 34:24-36.

Smetanin, A.V. et al. 1970. TsIT i ego metody NOT. Moscow: Ekonomika.

Smith, Laurence D. 1990. "Metaphors of Knowledge and Behavior in the Behaviorist Tradition." In Metaphors in the History of Psychology, edited by David E. Leary, 239-66. Cambridge, UK: Cambridge University Press

Sobolev, Sergey. 1963. "Da, eto vpolne ser’ëzno!” In Vozmozhnoye i nevozmozhnoye v kibernetike, edited by Aksel' I. Berg and Ernest Kol'man, 82-88. Moscow: AN SSSR.

Star, Susan L. 1989. Regions of the Mind: Brain Research and the Quest for Scientific Certainty. Stanford, Calif.: Stanford University Press. 
Stites, Richard. 1989. Revolutionary Dreams: Utopian Vision and Experimental Life in the Russian Revolution. New York: Oxford University Press.

Teplov, Lev P. 1963. Ocherki o kibernetike, 2nd ed. Moscow: Moskovskiy rabochiy.

Todes, Daniel P. 2001. Pavlov's Physiology Factory: Experiment, Interpretation, Laboratory Enterprise. Baltimore and London: Johns Hopkins University Press.

Toulmin, Stephen. 1993. "From Clocks to Chaos: Humanizing the Mechanistic World-View." In The Machine as Metaphor and Tool, edited by Hermann Haken, Anders Karlqvist, and Uno Svedin, 139-53. Berlin: Springer-Verlag.

Toulmin, Stephen, and June Goodfield. 1962. The Architecture of Matter. New York: Harper \& Row.

Tsetlin, Mikhail L. 1973. Automaton Theory and Modeling of Biological Systems, translated by Scitran. New York: Academic Press.

Vayl', Pëtr, and Aleksandr Genis. 1996. 60-e: Mir sovetskogo cheloveka. Moscow: Novoye literaturnoye obozreniye.

Vartanian, Aram. 1973. "Man-Machine from the Greeks to the Computer." In Dictionary of the History of Ideas: Studies of Selected Pivotal Ideas, vol. III, 131-46. New York: Charles Scribner's Sons.

Vucinich, Alexander. 1984. Empire of Knowledge: The Academy of Sciences of the USSR (1917-1970). Berkeley, Calif.: University of California Press.

Whiting, H.T.A., ed. 1984. Human Motor Actions: Bernstein Reassessed. Amsterdam: North Holland.

Wiener, Norbert. [1948] 1961. Cybernetics, or Control and Communication in the Animal and the Machine. Cambridge, Mass.: MIT Press.

Wiener, Norbert. [1950] 1967. The Human Use of Human Beings: Cybernetics and Society. New York: Avon Books.

Williams, Raymond. 1985. Keywords: A Vocabulary of Culture and Society, revised ed. New York: Oxford University Press. 